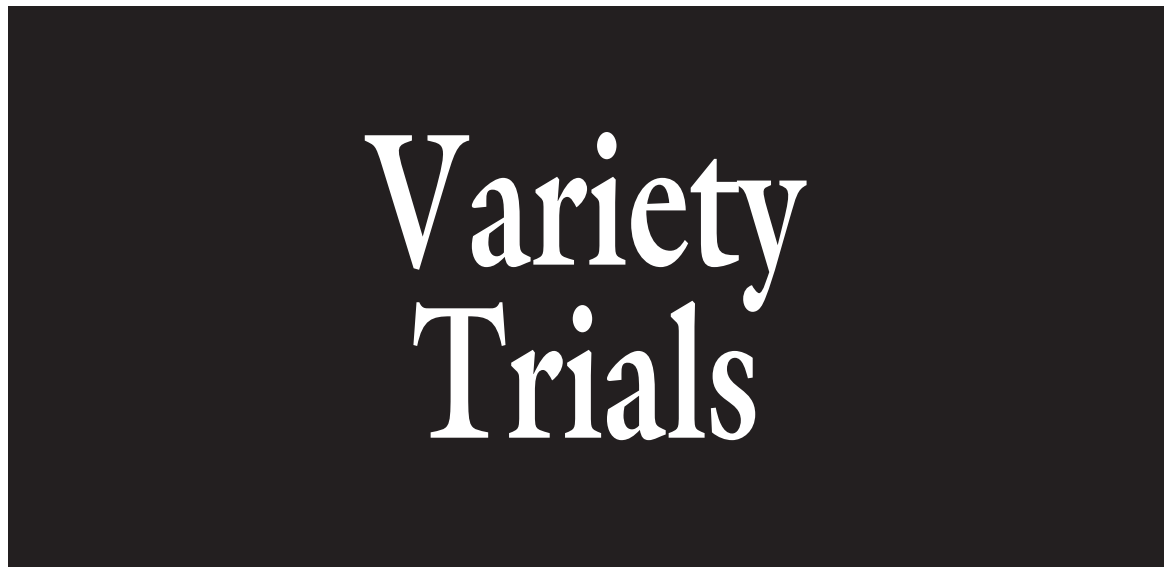

\title{
Pennsylvania Statewide Winter Squash Cultivar Evaluation
}

\author{
Elsa S. Sánchez ${ }^{1,7,12}$, Thomas M. Butzler ${ }^{2,8}$, Lee J. Stivers ${ }^{3,9}$, \\ Timothy E. Elkner ${ }^{4,9}$, Steven M. Bogash ${ }^{5,10}$, \\ R. Eric Oesterling ${ }^{6,10}$, and Michael D. Orzolek ${ }^{1,11}$
}

AdDITIONAL INDEX WORDS. variety trial, Cucurbita, acorn squash, butternut squash, buttercup squash, kabocha squash

\begin{abstract}
SUMMARY. Butternut, acorn, and buttercup/kabocha winter squash (Cucurbita sp.) cultivars were evaluated in a conventional system in central, southeastern, and southwestern Pennsylvania in 2010-11. Results from individual locations were used to create statewide recommendations, which are also relevant for the mid-Atlantic U.S. region. Additionally, butternut and acorn cultivars were evaluated in an organic system in central Pennsylvania. In a conventional system, butternut cultivars JWS6823, Betternut 401, Quantum, and Metro are recommended based on equal or higher marketable yield than the standard Waltham Butternut. Acorn squash cultivars that performed equally to or better than the standard, Tay Belle, were Table Star, Harlequin, and Autumn Delight. In the kabocha/buttercup category, 'Sweet Mama' and 'Red Kuri' had marketable yields not different from the standard 'Sunshine' in central and southeastern Pennsylvania. In the organic system, butternut cultivars JWS6823, Betternut 401, and Metro all had marketable yields not different from the standard Waltham Butternut. For acorn cultivars, Celebration yield did not differ from the standard Table Queen.
\end{abstract}

W inter squashes are valued for their edible and ornamental uses. They are sources of vitamin A, beta-carotene, potassium, vitamin $\mathrm{C}$, and fiber [Pennsylvania Department of Public Welfare (DPW), 2005; U.S. Department of Agriculture (USDA), 2012]. Having a mild to very sweet flavor depending on type (DPW, 2005), they are used in savory as well as sweet preparations. Additionally, many have attractive exocarps and are used in tablescapes and other decorative ways. Their hard, thick exocarp also allows for long shelf life and, as a result, they are a good crop for extending the marketing season into December or beyond in temperate areas.
In Pennsylvania, 383 acres were devoted to winter squash on 210 farms, ranking eleventh and sixth in the nation, respectively (USDA, 2009). Pennsylvania ranks seventh nationally in number of organic farms producing vegetables, potatoes (Solanum tuberosum), and melons (Cucumis sp.)
(USDA, 2010). Pennsylvania's 151 organic farms span 1194 acres with a value of $\$ 14,148,101$. About a third of these farms (53) grow squash on over 170 acres. This places Pennsylvania seventh in the nation in number of organic farms growing squash. Winter squash cultivars have not been evaluated for a number of years in the mid-Atlantic U.S. region. Market outlets for growers have extended into the fall/winter season and winter squash have an important niche in the late-season. It is anticipated that the winter squash market has room for increased growth. As such butternut, acorn, and buttercup/kabocha winter squash cultivars were evaluated in conventional and organic systems to develop recommendations relevant for the mid-Atlantic U.S. region.

\section{Materials and methods}

To capture the varying environmental conditions across the state, evaluation sites for the conventional system were located in central Pennsylvania at the Russell E. Larson Research and Education Center, Rock Springs (lat. $40^{\circ} 42^{\prime} 45.04^{\prime \prime} \mathrm{N}$, long $\left.77^{\circ} 57^{\prime} 12.44^{\prime \prime} \mathrm{W}\right)$; in southeastern Pennsylvania at the Southeast Agricultural Research and Extension Center, Manheim (lat. $40^{\circ} 07^{\prime} 05.11^{\prime \prime} \mathrm{N}$, long. $\left.76^{\circ} 25^{\prime} 45.69^{\prime \prime} \mathrm{W}\right)$; and in southwestern Pennsylvania at a growers' field (Harvest Valley Farms) in Valencia (lat. $40^{\circ} 4 \mathrm{l}^{\prime} 22.8 \mathrm{I}^{\prime \prime} \mathrm{N}$, long. $79^{\circ} 55^{\prime} 28.05^{\prime \prime} \mathrm{W}$ ) (Fig. 1). The organic evaluation was conducted at the central Pennsylvania site.

Cultivars evaluated were selected after conversations with seed company representatives. They were selected based on potential to produce higher yields than recommended standards: 'Waltham Butternut' for butternut squash, 'Tay Belle' for acorn squash in the conventional system and 'Table Queen' in the organic system, and 'Sunshine' for buttercup/ kabocha squash (Tables 1 and 2).

\begin{tabular}{llll}
\hline $\begin{array}{l}\text { Units } \\
\text { To convert U.S. to SI, } \\
\text { multiply by }\end{array}$ & U.S. unit & SI unit & $\begin{array}{l}\text { To convert SI to U.S., } \\
\text { multiply by }\end{array}$ \\
\hline 0.4047 & acre(s) & $\mathrm{ha}$ & 2.4711 \\
102.7902 & acre-inch $(\mathrm{es})$ & $\mathrm{m}^{3}$ & 0.0097 \\
0.3048 & $\mathrm{ft}$ & $\mathrm{m}$ & 3.2808 \\
2.54 & inch(es) & $\mathrm{cm}$ & 0.3937 \\
0.4536 & $\mathrm{lb}$ & $\mathrm{kg}$ & 2.2046 \\
1.1209 & $\mathrm{lb} / \mathrm{acre}$ & $\mathrm{kg} \cdot \mathrm{ha}^{-1}$ & 0.8922 \\
0.0254 & mil & $\mathrm{mm}$ & 39.3701
\end{tabular}




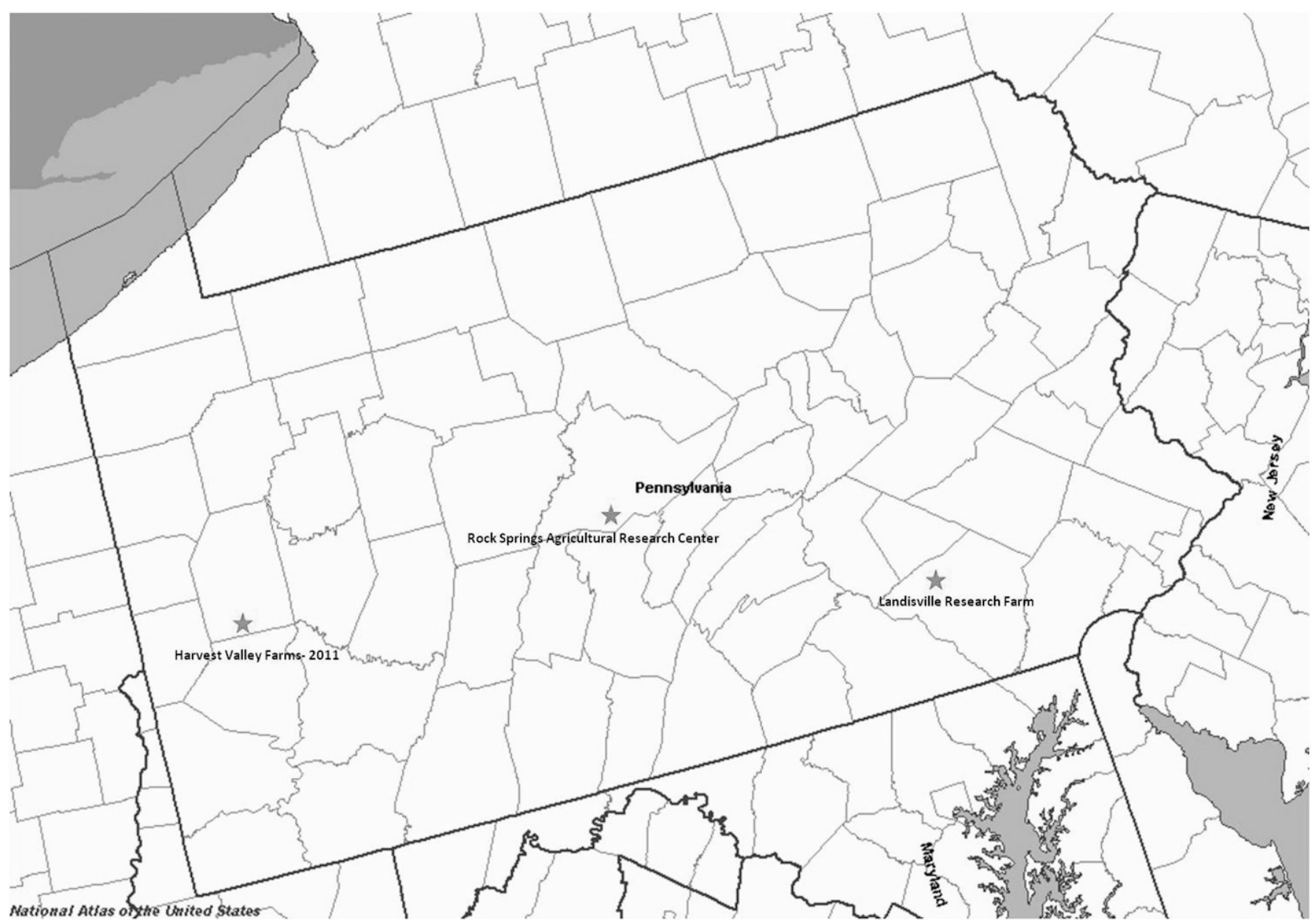

Fig. 1. Winter squash cultivar evaluation sites at southwestern, central, and southeastern Pennsylvania in $2010-11$.

'Waltham Butternut' has been considered an industry standard butternut squash ever since it received All-America Selections winner status in 1970.

The authors acknowledge the Pennsylvania Vegetable Research and Marketing Board for funding this project. We also thank our on-farm collaborator at Harvest Valley Farms, Valencia, PA, as well as High Mowing Seeds, Johnny's Selected Seeds, New England Seed Company, Rupp Seeds Inc., Seedway LLC, and Seigers Seed Company for their generous donation of seeds used in this study. We also thank our families for their support.

Use of trade names does not imply endorsement of the products named or criticism of similar ones not named.

${ }^{1}$ Pennsylvania State University Horticulture, University Park, PA 16802

${ }^{2}$ Penn State Extension, Mill Hall, PA 17751

${ }^{3}$ Penn State Extension, Washington, PA 15301

${ }^{4}$ Penn State Extension, Lancaster, PA 17601

${ }^{5}$ Penn State Extension, Chambersburg, PA 17202

${ }^{6}$ Penn State Extension, Greensburg, PA 15601

${ }^{7}$ Associate Professor

${ }^{8}$ Extension Educator

${ }^{9}$ Senior Extension Educator

${ }^{10}$ Associate Extension Educator

${ }^{11}$ Professor

${ }^{12}$ Corresponding author. E-mail: esanchez@psu.edu.
'Tay Belle' has been recommended since the 1990s (Orzolek et al., 1999), and 'Table Queen' was available as untreated seed and has also been recommended since the 1990s (Orzolek et al., 1999). 'Sunshine' became an AllAmerica Selections winner in 2004 and has been recommended for the mid-Atlantic U.S. region since 2005 (Orzolek et al., 2005). 'Red Kuri' and 'Sweet Lightening' are mini red hubbard and delicata types, respectively. They were included in the evaluation because their size characteristics and aesthetics are similar to buttercup/ kabocha types.

Cultivars were arranged in a randomized complete block design with four replications and six plants per cultivar in each block. Black embossed plastic mulch (1 mil; Sigma Plastics Group, Allentown, PA) with drip tape (T-Tape model 508-12-450; John Deere, Moline, IL) centered on 3-ftwide and 6-inch-high raised beds was applied before planting. Plants were spaced $3 \mathrm{ft}$ apart in a single row on beds on 8 -ft centers. Irrigation was scheduled to provide 1 to 1.5 acre-inch water per week.

Conventional system. Pests and weeds were managed following recommendations for commercial production of winter squash (Orzolek et al., 2010).

At the central site, 4-week-old transplants were planted on 17 June 2010 and 3 -week-old transplants on 14 June 2011 . Fruit were harvested as individual cultivars reached maturity: 1 and 7 Sept. 2010 and 26 Sept. 2011 for butternut squash; $30 \mathrm{Aug} ., 3$ and 7 Sept. 2010, and 21 Sept. 2011 for acorn squash; and 1, 2, 3, and 7 Sept. 2010 and 18, 19, and 26 Sept. 2011 for buttercup/kabocha squash. The soil was a Hagerstown silt loam. Phosphorus $(\mathrm{P})$ at a rate of $58.7 \mathrm{lb} /$ acre and potassium $(\mathrm{K})$ at a rate $89.3 \mathrm{lb} /$ acre were applied based on soil test results. Nitrogen $(\mathrm{N})$ was applied preplant at a rate of $75 \mathrm{lb} /$ acre (Orzolek et al., 2010).

At the southeastern site, direct seeding occurred on 16 June 2010 
Table 1. Cultivars and seed sources of winter squash evaluated in a conventional system in central, southeastern, and southwestern Pennsylvania in 2010-11. The standards 'Waltham Butternut' in the butternut, 'Tay Belle' in the acorn, and 'Sunshine' in the buttercup/kabocha categories were grown for comparisons.

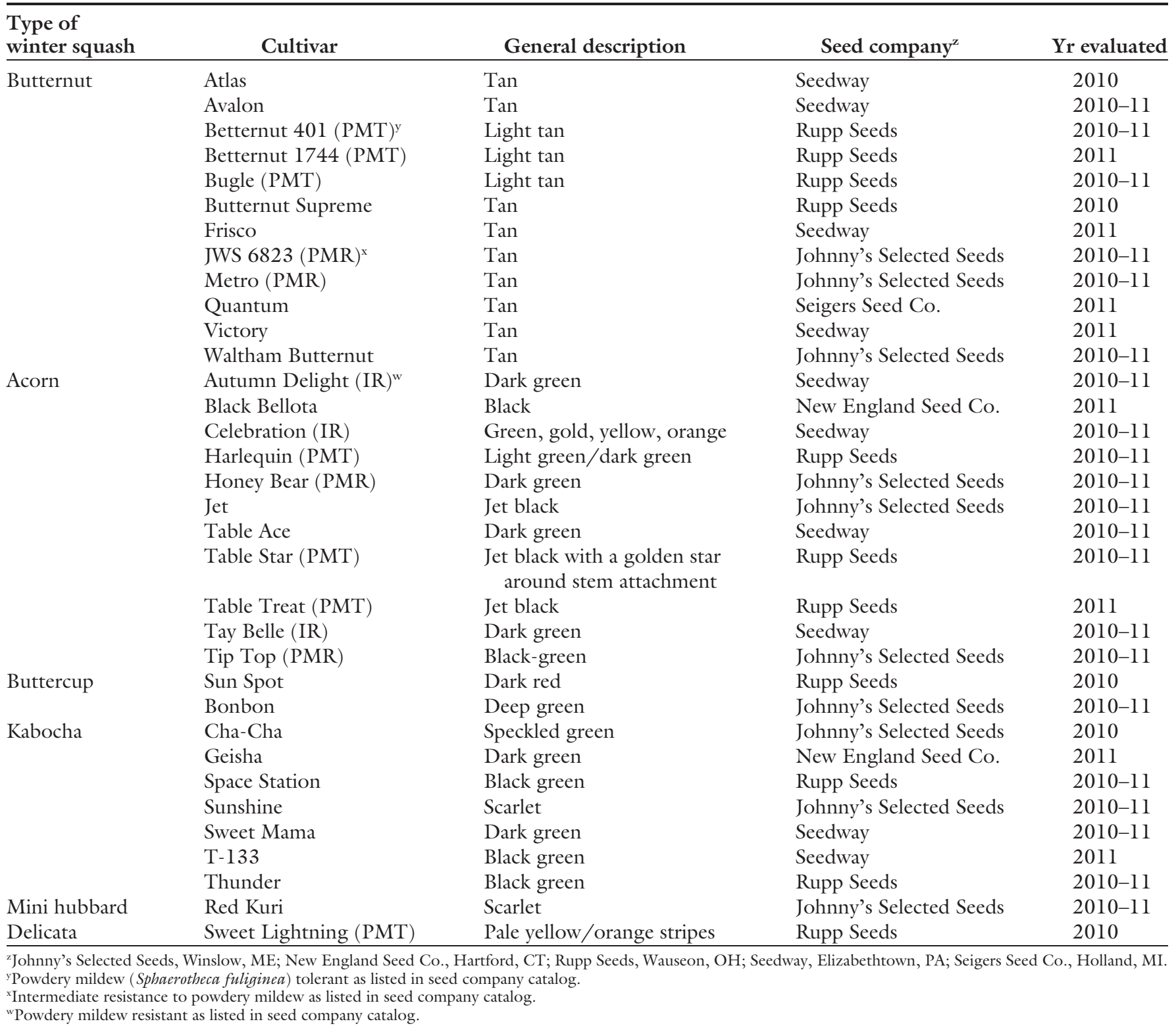

and 15 June 2011. Acorn cultivars were harvested on 19-20 Oct. 2010 and 11-12 Oct. 2011. All other cultivars were harvested on 28-29 Oct. 2010 and $24-25$ Oct. 2011 . The soil was a Hagerstown silt loam. Nitrogen was applied both years at a rate of 90 $\mathrm{lb} / \mathrm{acre}$, with $50 \mathrm{lb} /$ acre applied preplant and the remaining $40 \mathrm{lb} /$ acre through fertigation events. Phosphorus and $\mathrm{K}$ were applied preplant based on soil test results.

In 2010, cultivars were direct seeded in early July, about 3 weeks late and into poor soil conditions at the southwestern site. A crop failure was determined on 21 July with each plot averaging two plants; data were not collected. About 2-week-old transplants were planted on 24 June 2011. Butternut and buttercup/kabocha squash were harvested on 13 Oct. 2011 and acorn on 27 Sept. 2011. The soil was a Cavode silt loam. Fertilizer was applied preplant to the mulched area at a rate of $320 \mathrm{lb} /$ acre with a mixture of $50 \%$ urea and $50 \%$ $19 \mathrm{~N}-8.3 \mathrm{P}-15.8 \mathrm{~K}$. At transplanting, $10 \mathrm{lb} /$ acre of $12 \mathrm{~N}-21.1 \mathrm{P}-6.6 \mathrm{~K}$ was applied. A total of $105.2 \mathrm{lb} /$ acre $\mathrm{N}$, $18.2 \mathrm{lb} /$ acre $\mathrm{P}$, and $20.2 \mathrm{lb} /$ acre K was applied through these fertilization events.

Organic SYstem. Five-week-old transplants were planted on 28-29 June 2010 and 3-week-old transplants on 21 June 2011 in a field under organic management since 2006; however, it was not certified organic. Nitrogen was applied at a rate of $75 \mathrm{lb} /$ acre with $5 \mathrm{~N}-0.4 \mathrm{P}-0.8 \mathrm{~K}$ (Blue N 5-l-1; Fertrell, Bainbridge, PA). Soil analysis showed $\mathrm{P}$ and $\mathrm{K}$ amendment was not needed. Weeds were managed with timely cultivation. Pest populations remained below levels warranting management. Harvest occurred on 9 Sept. 2010 and 19-20 Sept. 2011.

All data were analyzed with General Linear Model analysis of variance using SAS (version 9.1.3; SAS Institute, Cary, NC). When significant effects at probability less than or equal to 0.05 were detected, Duncan's least 
Table 2. Cultivars and seed sources of winter squash evaluated in an organic system in central PA in 2010-11. The standards 'Waltham Butternut' in the butternut category and 'Table Queen' in the acorn category were grown for comparisons.

\begin{tabular}{|c|c|c|c|c|c|}
\hline $\begin{array}{l}\text { Type of } \\
\text { winter squash }\end{array}$ & Cultivar & General description & Seed company ${ }^{z}$ & $\begin{array}{c}\text { Organic or } \\
\text { nontreated seed }\end{array}$ & Yr evaluated \\
\hline \multirow[t]{3}{*}{ Butternut } & Betternut $401(\text { PMT })^{y}$ & Light tan & Rupp Seeds & Nontreated & $2010-11$ \\
\hline & JWS 6823 (PMR) ${ }^{x}$ & Tan & Johnny's Selected Seeds & Nontreated & $2010-11$ \\
\hline & Waltham Butternut & Tan & Seedway & Organic & $2010-11$ \\
\hline \multirow[t]{7}{*}{ Acorn } & Autumn Delight (IR) ${ }^{\mathrm{w}}$ & Dark green & Seedway & Nontreated & $2010-11$ \\
\hline & Honey Bear (PMR) & Dark green & Johnny's Selected Seeds & Nontreated & $2010-11$ \\
\hline & Jet & Jet black & Johnny's Selected Seeds & Nontreated & $2010-11$ \\
\hline & REBA (PMR) & Black green & High Mowing Seeds & Organic & $2010-11$ \\
\hline & Table Queen & Dark green & High Mowing Seeds & Organic & $2010-11$ \\
\hline & Tay Belle (IR) & Dark green & Seedway & Nontreated & 2010 \\
\hline & Tip Top (PMR) & Black-green & Johnny's Selected Seeds & Nontreated & $2010-11$ \\
\hline
\end{tabular}

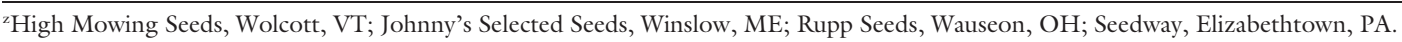

y Powdery mildew (Sphaerotheca fuliginea) tolerant as listed in seed company catalog.

'Powdery mildew resistant as listed in seed company catalog.

"Intermediate resistance to powdery mildew as listed in seed company catalog.

significant difference test was used to separate cultivar means. Data from each site were analyzed separately to account for different cultural methods used at each site.

\section{Results and discussion Conventional System}

BUTTERNUT SQUASH-CENTRAL Pennsylvania. In 2010, 'Bugle' and 'Betternut 401' produced a larger number of fruit while fruit numbers from the other cultivars were not different from 'Waltham Butternut' (Table 3). In 2011, 'Quantum' and 'Bugle' produced a larger number of fruit and all others were not different from 'Waltham Butternut'.

In 2010, 'Atlas' produced the largest marketable yield by weight. Fruit weight from all other cultivars was not different from 'Waltham Butternut'. In 2011, 'Quantum' was higher and all other cultivars were not different from 'Waltham Butternut'.

In 2010, individual fruit weight from 'Atlas' was higher and 'Bugle' lower than 'Waltham Butternut'. The remaining cultivars were not different from 'Waltham Butternut'. In 2011, individual fruit weight from 'Quantum' was higher and all other cultivars lower than 'Waltham Butternut'.

Very few fruit were unmarketable and, in 2010, differences in unmarketable yields between cultivars were not detected (Table 4). In 2011, 'Bugle' produced higher unmarketable yields in terms of number and weight and all other cultivars were not different from 'Waltham Butternut'.
The cultivars Bugle, Betternut 401, JWS 6823, and Metro are recommended as they performed equally well or better than Waltham Butternut in the number of fruit produced and fruit weight per plant. For markets where small fruit is desired, ' $\mathrm{Bu}$ gle' is recommended as individual fruit were smaller than 'Waltham Butternut'. 'Butternut Supreme', 'Atlas', 'Betternut 1744', and 'Quantum' were evaluated in only one year of the study; therefore, location-specific recommendations cannot be made.

Southeastern Pennsylvania. In 2010, the number of marketable fruit produced by 'Atlas' was lower and the remaining cultivars were not different from 'Waltham Butternut' (Table 3). In 2011, 'Victory' produced a larger number of fruit and all other cultivars were not different from 'Waltham Butternut'.

In 2010, marketable fruit weight from 'Quantum' was higher and 'Bugle' lower than 'Waltham Butternut'. Fruit weight per plant from all other cultivars was not different from 'Waltham Butternut'. In 2011, 'Quantum' and 'Frisco' produced higher marketable fruit by weight and all other cultivars were not different from 'Waltham Butternut'.

In 2010, individual fruit weight was higher from 'Atlas', 'Butternut Supreme', and 'Quantum' and lower from 'JWS 6823' and 'Bugle' than 'Waltham Butternut'. All other cultivars were not different from 'Waltham Butternut'. In 2011, individual fruit weight was higher from 'Frisco',
'Quantum', and 'Avalon' and lower from 'Bugle' than 'Waltham Butternut'. All other cultivars were not different from 'Waltham Butternut'.

In 2010, 'Atlas' produced more unmarketable fruit in terms of weight and number than all other cultivars that were not different from each other (Table 4). In 2011, differences in unmarketable yields between cultivars were not detected.

The cultivars JWS 6823, Betternut 401, Metro, Quantum, and Avalon are recommended as they performed equally well or better than Waltham Butternut in the number of fruit produced and fruit weight per plant. 'Butternut Supreme', 'Victory', 'Betternut 1744', and 'Frisco' were only evaluated in one year; therefore, location-specific recommendations cannot be made.

Southwestern Pennsylvania2011 ONLY. Because of animal damage, 'Waltham Butternut' was not used as the standard. Differences in marketable yields by number and individual fruit weight were not detected between cultivars (Table 3 ). 'Quantum' produced the highest marketable yields by weight compared with all other cultivars that were not different from each other. Differences in unmarketable yields between cultivars were not detected (Table 4).

ACORN SQUASH-CENTRAL Pennsylvania. In 2010, 'Harlequin' and 'Celebration' produced a larger number of marketable fruit with all other cultivars not different from 'Tay Belle' (Table 5). In 2011, 


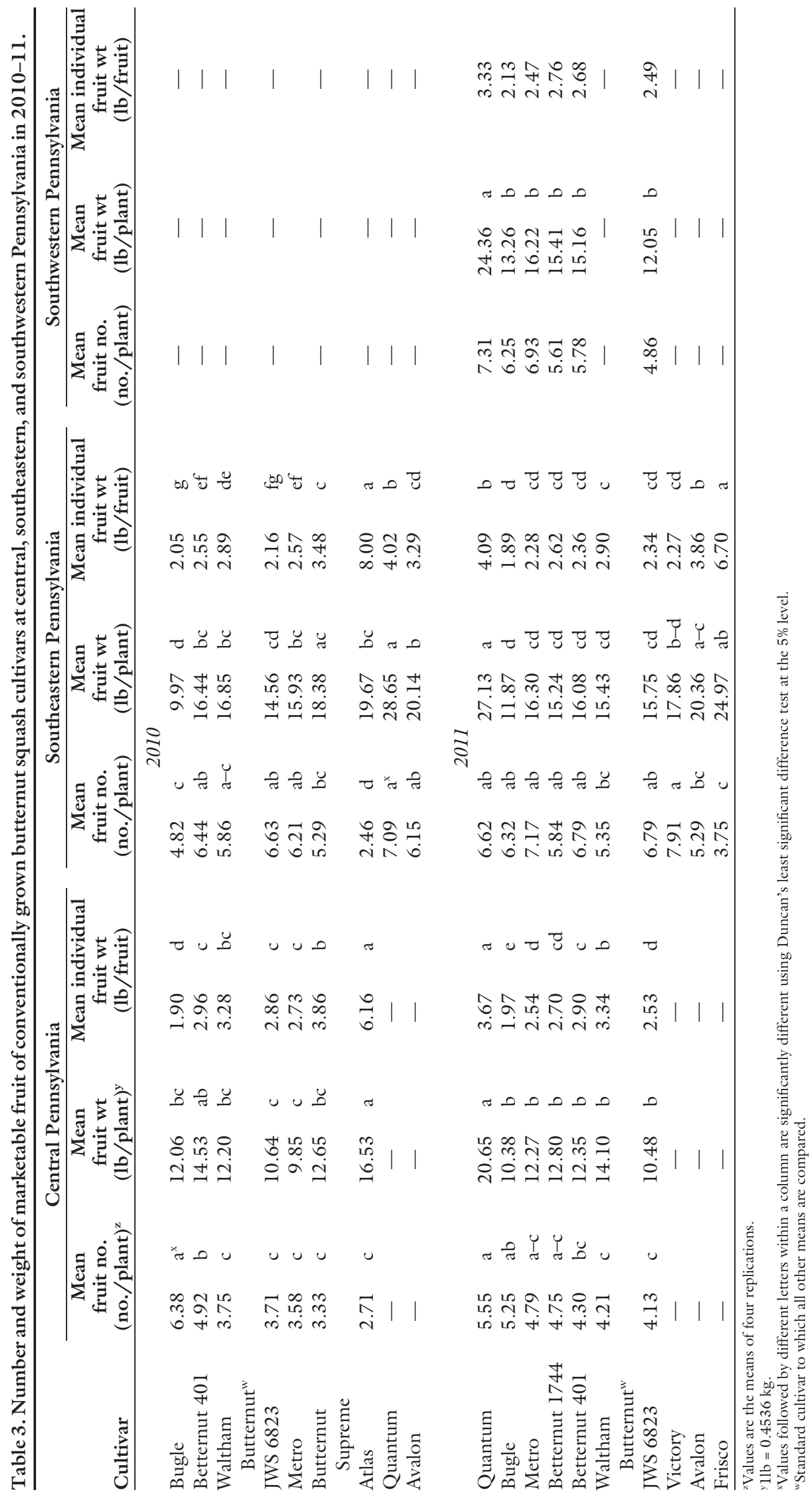


Table 4. Number and weight of unmarketable fruit of conventionally grown butternut squash cultivars at central, southeastern, and southwestern Pennsylvania in 2010-11.

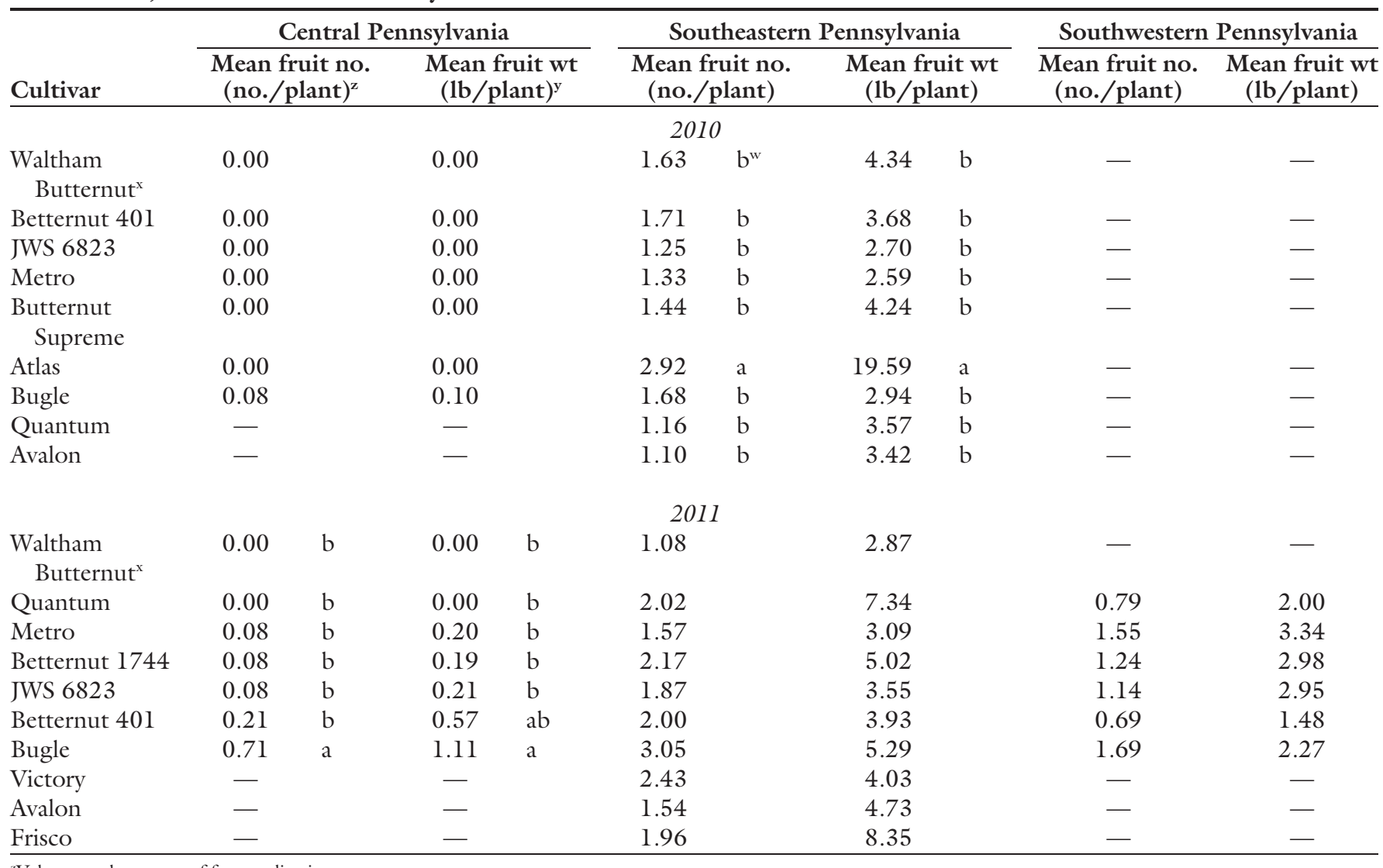

${ }^{z}$ Values are the means of four replications.

${ }^{y} \mathrm{l} \mathrm{lb}=0.4536 \mathrm{~kg}$.

x Standard cultivar to which all other means are compared.

"Values followed by different letters within a column are significantly different using Duncan's least significant difference test at the $5 \%$ level.

'Celebration', 'Harlequin', and 'Table Star' produced a larger number and 'Jet' a smaller number of marketable fruit than 'Tay Belle'. All other cultivars were not different from 'Tay Belle'.

In 2010, 'Celebration', 'Tip Top', and 'Honey Bear' had a lower fruit weight with all other cultivars not different from 'Tay Belle'. In 2011, 'Jet', 'Table Treat', and 'Honey Bear' produced lower fruit weight with all remaining cultivars not different from 'Tay Belle'.

In 2010, 'Tip Top', 'Table Star', 'Harlequin', 'Celebration', and 'Honey Bear' had a lower individual fruit weight with the remaining cultivars not different from 'Tay Belle'. In 2011 , individual fruit weight of 'Jet' was higher and 'Table Treat', 'Table Star', 'Honey Bear', 'Harlequin', and 'Celebration' lower than 'Tay Belle'. The remaining cultivars were not different from 'Tay Belle'.

While unmarketable yields were minimal in 2010, 'Table Star' produced more unmarketable fruit by number and weight than all other cultivars that were not different from each other (Table 6). In 2011, 'Jet' produced higher unmarketable yields by number and weight than 'Tay Belle', which was not different from any other cultivar.

The cultivars Harlequin, Table Star, and Autumn Delight are recommended as they outperformed or performed as well as 'Tay Belle'. For markets with demand for smaller acorn squash, 'Table Star' and 'Harlequin' produced smaller individual fruit weight than 'Tay Belle'. Although evaluated only in one year, 'Black Bellota' did not differ from 'Tay Belle'.

Southeastern Pennsylvania. In 2010, 'Harlequin', 'Table Star', 'Celebration', 'Black Bellota', and 'Honey Bear' produced more marketable fruit with the other cultivars not different from 'Tay Belle' (Table 5). In 2011, 'Table Star' produced higher and 'Honey Bear' lower marketable yields in terms of number than 'Tay Belle'. All other cultivars were not different from 'Tay Belle'.

In 2010, 'Harlequin', 'Table Star', and 'Black Bellota' fruit weight per plant was higher while all other cultivars were not different from 'Tay Belle'. In 2011, 'Table Star' produced higher and 'Table Queen' and 'Honey Bear' lower fruit weight per plant than 'Tay Belle'. All other cultivars were not different from 'Tay Belle'.

In 2010, individual fruit weight from 'Jet' was higher and 'Autumn Delight' not different from 'Tay Belle'. The remaining cultivars were lower than 'Tay Belle'. In 2011, individual fruit weight from 'Jet' was higher and 'Table Queen', 'Honey Bear', and 'Celebration' lower than 'Tay Belle'. The remaining cultivars were not different from 'Tay Belle'.

In 2010 , the number of unmarketable fruit from 'Harlequin', 'Honey Bear', 'Table Treat', and 'Tip Top' was not different from 'Tay Belle' (Table 6). Unmarketable fruit from the remaining cultivars was less than 'Tay Belle'. By 


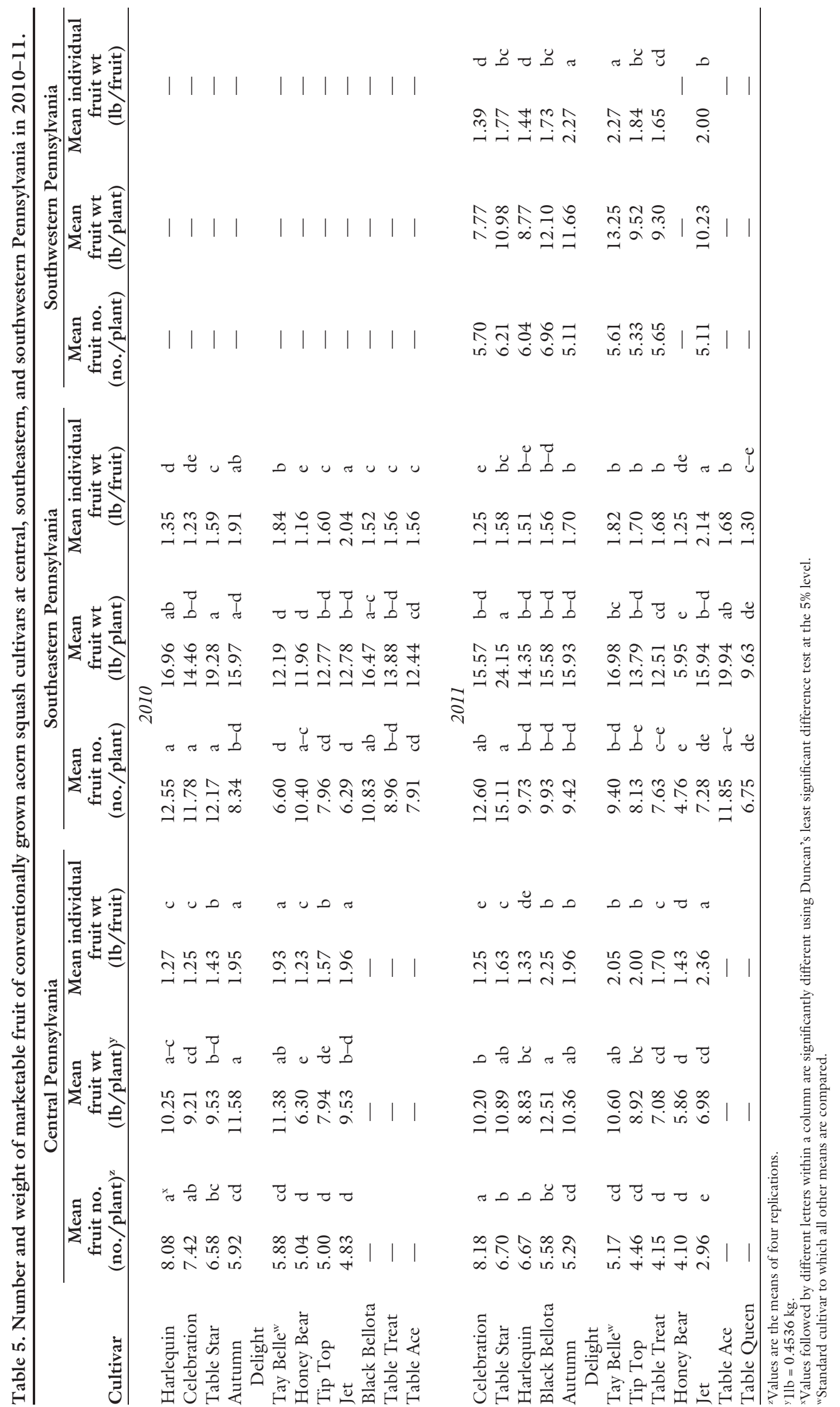


Table 6. Number and weight of unmarketable fruit of conventionally grown acorn squash cultivars at central, southeastern, and southwestern Pennsylvania in 2010-11.

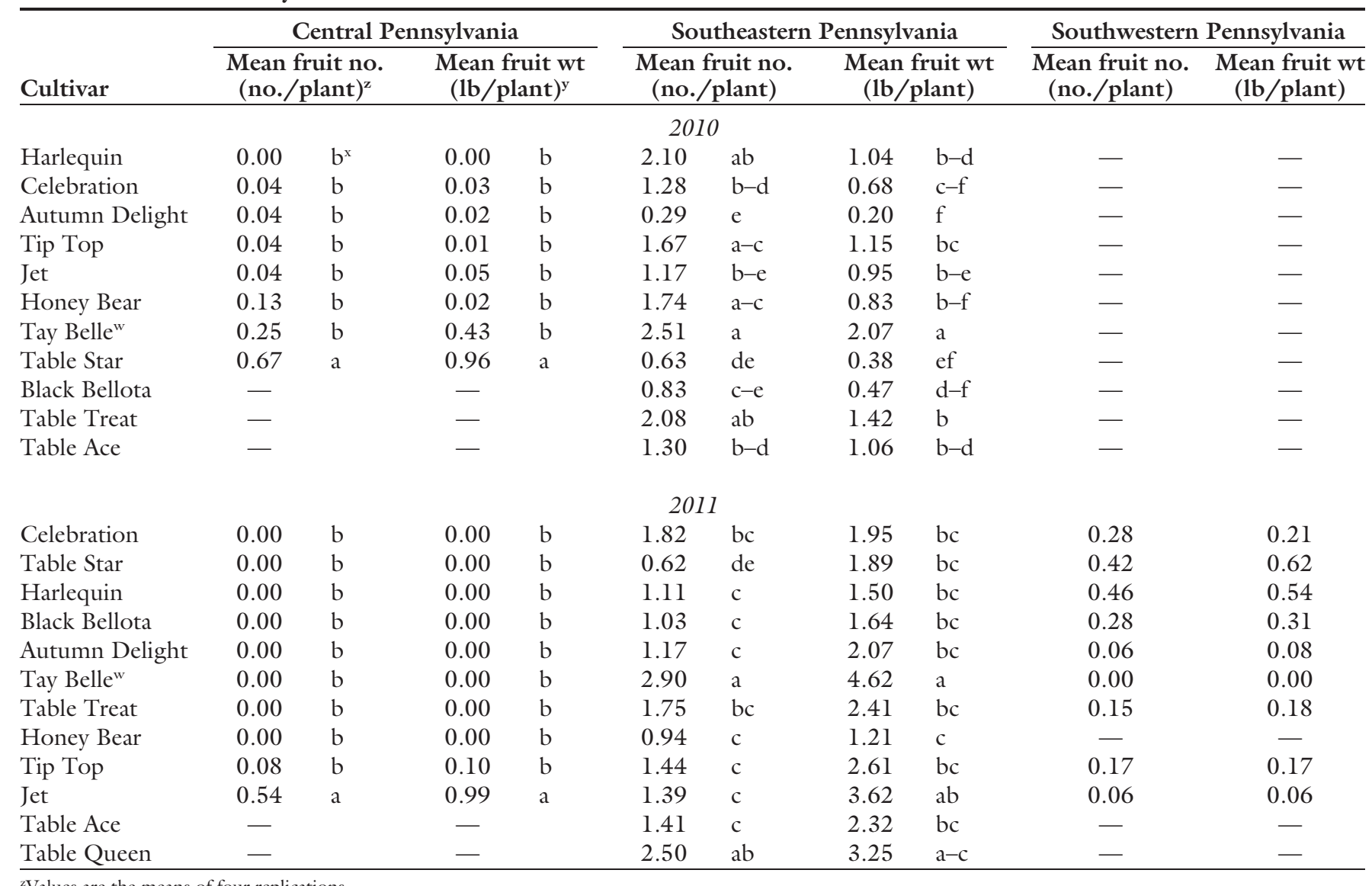

${ }^{2}$ Values are the means of four replications.

${ }^{y} 1 \mathrm{lb}=0.4536 \mathrm{~kg}$.

'Values followed by different letters within a column are significantly different using Duncan's least significant difference test at the $5 \%$ level.

wStandard cultivar to which all other means are compared.

weight, 'Tay Belle' produced the highest unmarketable fruit. In 2011, number of unmarketable fruit produced by 'Table Queen' was not different from 'Tay Belle' that produced a higher number of unmarketable fruit than all other cultivars. Unmarketable yield by weight from 'Table Queen' and 'Jet' was not different from 'Tay Belle' that was higher than all other cultivars.

'Harlequin', 'Table Star', 'Celebration', 'Black Bellota', 'Table Treat', 'Autumn Delight', 'Tip Top', 'Table Ace', and 'Jet' are recommended as they performed as well as or better than 'Tay Belle' in terms of number and weight of fruit per plant. 'Jet' produced larger individual fruit than 'Tay Belle'.

Southwestern Pennsylvania2011 onLY. No differences were observed in marketable fruit number or weight per plant or unmarketable yields (Tables 5 and 6). 'Tay Belle' and 'Autumn Delight' produced a higher individual fruit weight than all other cultivars.

BUTTERCUP AND KABOCHA types-Central Pennsylvania. In 2010, 'Sweet Lightening' and 'Sun Spot' produced a larger number of marketable fruit while the remaining cultivars were not different from 'Sunshine' (Table 7). In 2011, no differences in the number of fruit per plant were observed.

In 2010, fruit weight per plant from 'Bonbon' and 'Cha-Cha' was lower while the remaining cultivars were not different from 'Sunshine'. In 2011, 'Geisha' had higher and 'Space Station' lower fruit weight per plant than 'Sunshine'.

In 2010, 'Space Station', 'Sun Spot', and 'Sweet Lightening' had a lower individual fruit weight with the remaining cultivars not different from 'Sunshine'. In 2011, individual fruit weight from 'Geisha', 'Sweet Mama', and 'Red Kuri' was higher and 'Space Station' lower than 'Sunshine'. The remaining cultivars were not different from 'Sunshine'.

While very few fruit were unmarketable in 2010, 'Bonbon' and 'Cha-Cha' produced a larger number of unmarketable fruit with the remaining cultivars not different from 'Sunshine' (Table 8). 'Bonbon', 'Cha-Cha', 'Thunder', 'Space Station', and 'Sweet Mama' produced higher unmarketable fruit by weight while there was no difference for the remaining cultivars compared with 'Sunshine'. In 2011, no differences in unmarketable yield were observed.

'Red Kuri', 'Sweet Mama', and 'Thunder' are recommended. In terms of the number and weight of fruit per plant they performed equally to or better than 'Sunshine'. 'Sweet Lightening', 'Sun Spot', 'Geisha', and 'T133 ' were only evaluated in one year; therefore, location-specific recommendations cannot be made.

Southeastern Pennsylvania. In 2010, 'Sweet Lightening', 'Sun Spot', 


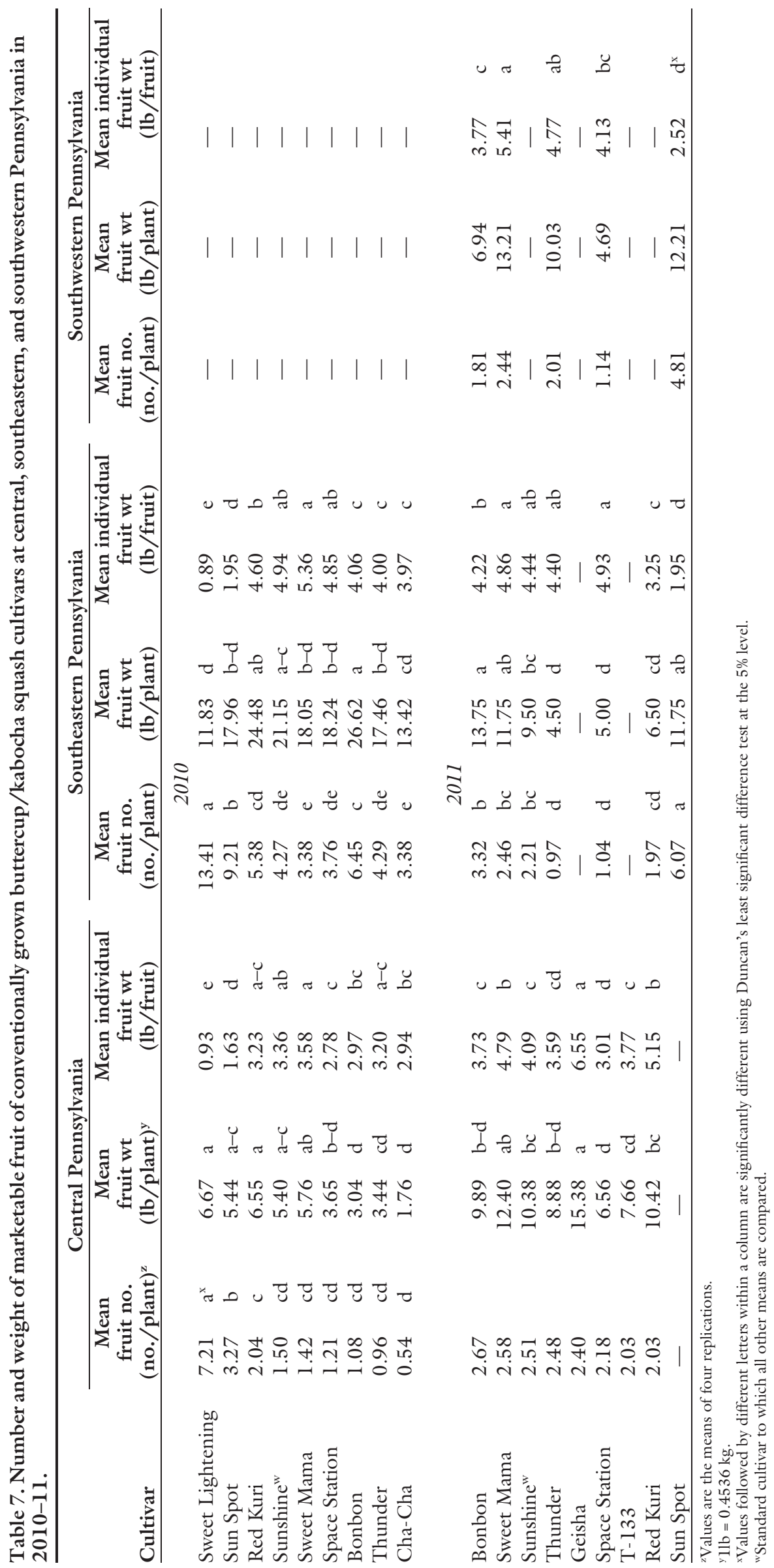


Table 8. Number and weight of unmarketable fruit of conventionally grown buttercup/kabocha squash cultivars at central, southeastern, and southwestern Pennsylvania in 2010-11.

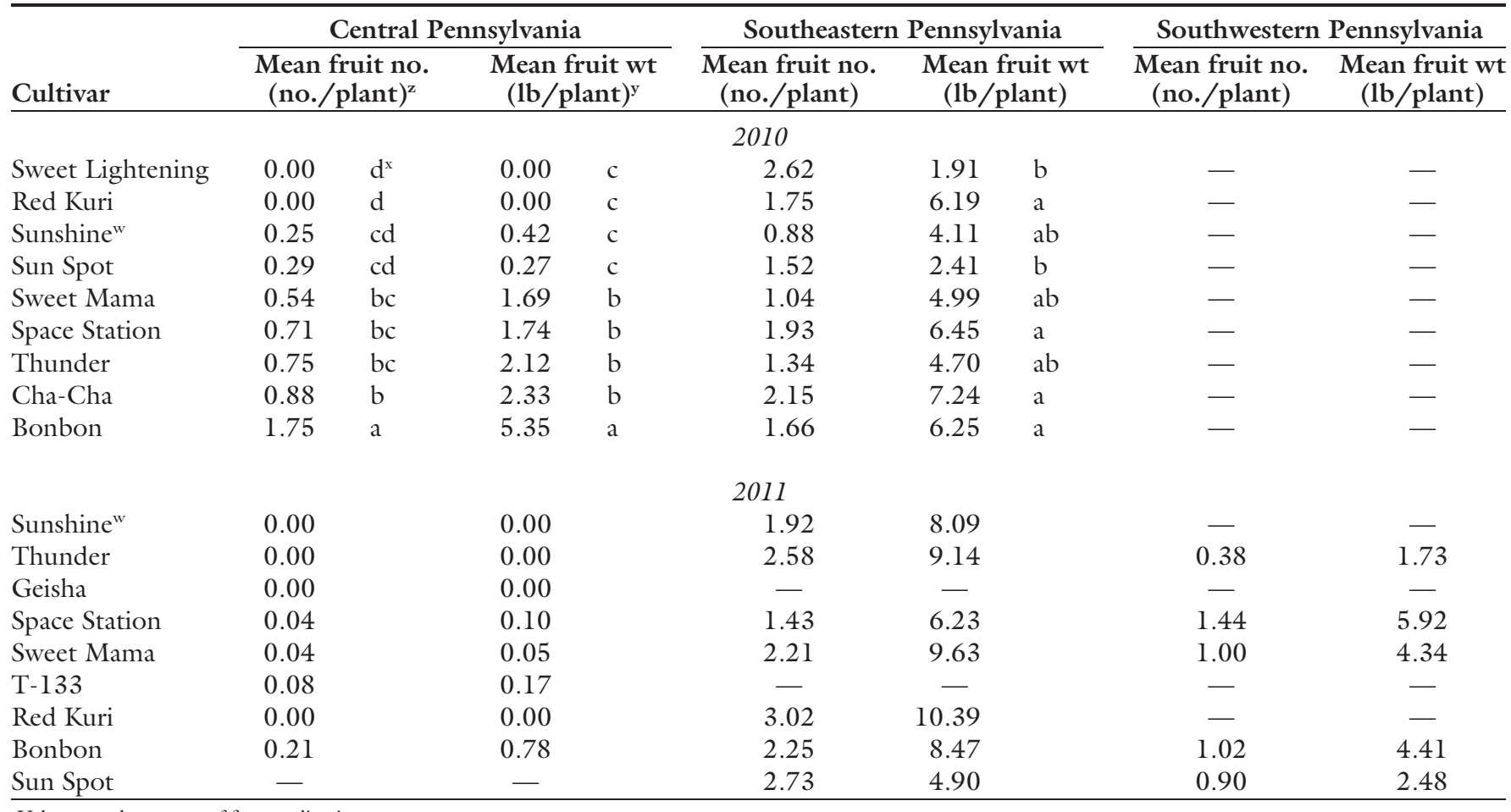

${ }^{\mathrm{z}}$ Values are the means of four replications.

${ }^{y} 1 \mathrm{lb}=0.4536 \mathrm{~kg}$.

'Values followed by different letters within a column are significantly different using Duncan's least significant difference test at the $5 \%$ level.

wStandard cultivar to which all other means are compared.

and 'Bonbon' produced a larger number of marketable fruit than 'Sunshine' (Table 7). The remaining cultivars were not different from 'Sunshine'. In 2011, 'Sun Spot' produced a higher and 'Thunder' and 'Space Station' a lower number of marketable fruit than 'Sunshine'. The remaining cultivars were not different from 'Sunshine'.
In 2010, fruit weight from 'Sweet Lightening' was lower while all other cultivars were not different when compared with 'Sunshine'. In 2011, marketable fruit weight was higher from 'Bonbon' and lower from 'Space Station' and 'Thunder' compared with 'Sunshine'. The remaining cultivars were not different from 'Sunshine'.
In 2010, 'Thunder', 'Bonbon', 'Sun Spot', 'Cha-Cha', and 'Sweet Lightening' produced a lower individual fruit weight than 'Sunshine'. The remaining cultivars were not different from 'Sunshine'. In 2011, 'Red Kuri' and 'Sun Spot' produced a lower individual fruit weight with the remaining cultivars not different from 'Sunshine'.

Table 9. Number and weight of marketable and unmarketable fruit of several cultivars of organically grown butternut squash in 2010-11.

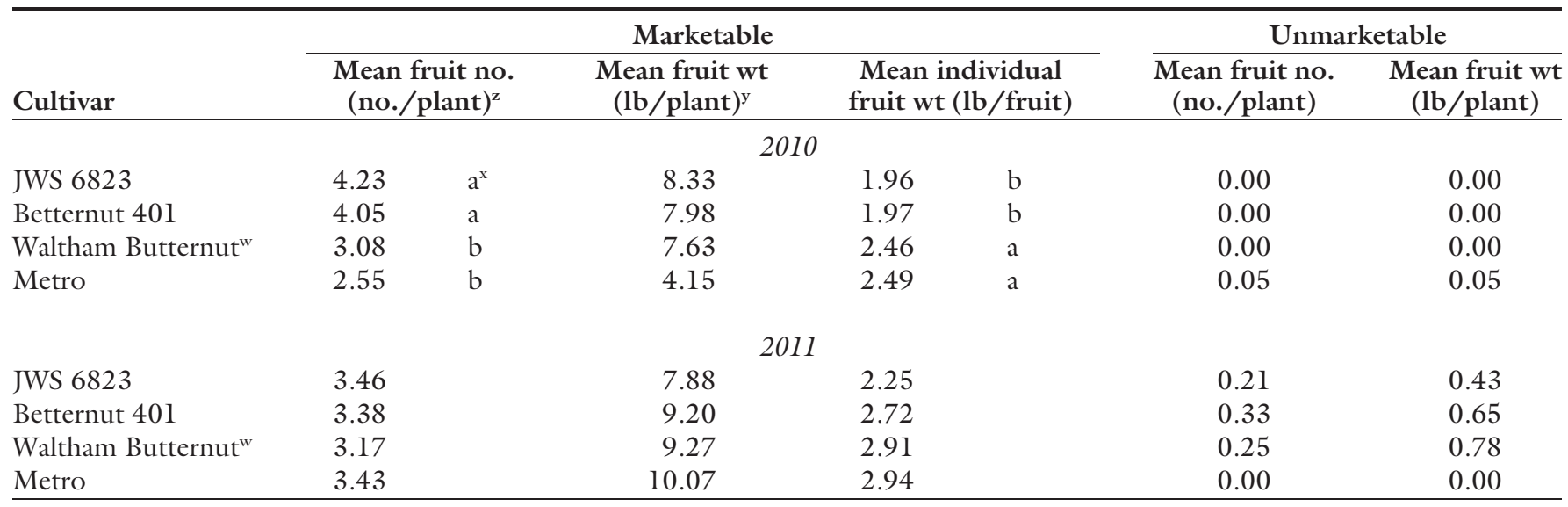

${ }^{2}$ Values are the means of four replications.

${ }^{\mathrm{y}} 1 \mathrm{lb}=0.4536 \mathrm{~kg}$.

'Values followed by different letters within a column are significantly different using Duncan's least significant difference test at the $5 \%$ level.

wStandard cultivar to which all other means are compared. 
Table 10. Number and weight of marketable and unmarketable fruit of several cultivars of organically grown acorn squash in 2010-11.

\begin{tabular}{|c|c|c|c|c|c|c|c|c|c|c|}
\hline \multirow[b]{2}{*}{ Cultivar } & \multicolumn{6}{|c|}{ Marketable } & \multicolumn{4}{|c|}{ Unmarketable } \\
\hline & \multicolumn{2}{|c|}{$\begin{array}{l}\text { Mean fruit no. } \\
{\text { (no./plant })^{\mathrm{z}}}^{\text {(no. }}\end{array}$} & \multicolumn{2}{|c|}{$\begin{array}{l}\text { Mean fruit wt } \\
\text { (lb/plant })^{y}\end{array}$} & \multicolumn{2}{|c|}{$\begin{array}{l}\text { Mean individual } \\
\text { fruit wt (lb/fruit) }\end{array}$} & \multicolumn{2}{|c|}{$\begin{array}{l}\text { Mean fruit no. } \\
\text { (no./plant) }\end{array}$} & \multicolumn{2}{|c|}{$\begin{array}{l}\text { Mean fruit wt } \\
\text { (lb/plant) }\end{array}$} \\
\hline Celebration & 5.53 & $a^{x}$ & 6.55 & b & 1.19 & $\mathrm{e}$ & 0.00 & & 0.00 & \\
\hline Tay Belle & 4.38 & $\mathrm{~b}$ & 7.80 & $\mathrm{a}$ & 1.79 & a & 0.00 & & 0.00 & \\
\hline REBA & 4.27 & $\mathrm{~b}$ & 5.67 & $\mathrm{bc}$ & 1.28 & de & 0.27 & & 0.30 & \\
\hline Jet & 3.83 & $b-d$ & 6.48 & $b$ & 1.69 & $a b$ & 0.10 & & 0.13 & \\
\hline Tip Top & 3.48 & $\mathrm{~cd}$ & 5.38 & $c$ & 1.56 & $\mathrm{bc}$ & 0.00 & & 0.00 & \\
\hline Autumn Delight & 3.40 & d & 6.03 & bc & 1.77 & $\mathrm{a}$ & 0.00 & & 0.00 & \\
\hline \multicolumn{11}{|c|}{2011} \\
\hline Celebration & 6.21 & $\mathrm{a}$ & 8.35 & $\mathrm{ab}$ & 1.35 & & 0.00 & $\mathrm{c}$ & 0.00 & b \\
\hline Jet & 2.04 & d & 4.26 & $\mathrm{~d}$ & 2.13 & & 1.79 & $\mathrm{a}$ & 3.10 & $\mathrm{a}$ \\
\hline Tip Top & 3.75 & c & 6.62 & $\mathrm{bc}$ & 1.76 & & 0.63 & b & 0.85 & b \\
\hline Autumn Delight & 4.73 & $\mathrm{bc}$ & 9.73 & $\mathrm{a}$ & 2.06 & & 0.00 & $\mathrm{c}$ & 0.00 & $\mathrm{~b}$ \\
\hline
\end{tabular}

${ }^{2}$ Values are the means of four replications

y $1 \mathrm{lb}=0.4536 \mathrm{~kg}$.

'Values followed by different letters within a column are significantly different using Duncan's least significant difference test at the $5 \%$ level.

wStandard cultivar to which all other means are compared.

In 2010 , differences in unmarketable yields in terms of fruit number per plant were not detected (Table 8). The unmarketable fruit weight per plant from all cultivars did not differ from 'Sunshine'. In 2011, differences in unmarketable yield were not detected.

'Sun Spot', 'Bonbon', 'Red Kuri', and 'Sweet Mama' are recommended as they performed equally to or better than 'Sunshine' in terms of number and weight of fruit per plant. When markets demand a smaller individual fruit, 'Sun Spot' is recommended. 'Cha-Cha' was only evaluated in one year; therefore, location-specific recommendations cannot be made.

Southwestern Pennsyluania2011 ONLY. Only two replications of 'Sunshine' plants were harvestable; therefore it was not used as a standard. Differences were not detected in marketable or unmarketable yields in terms of number or weight of fruit per plant (Tables 7 and 8). 'Sweet Mama' produced a higher individual fruit weight than 'Bonbon' followed by 'Sun Spot'. 'Thunder' and 'Space Station' produced intermediate individual fruit weight.

\section{Organic System}

BUTTERNUT SQUASH. In 2010, 'JWS 6823' and 'Betternut 401' produced a larger number of marketable fruit than 'Waltham Butternut' (Table 9). The number of fruit produced by 'Metro' was not different from 'Waltham Butternut'. In 2011, the number of fruit produced by all cultivars was not different from 'Waltham Butternut'.

In 2010-11, marketable yield by weight of all cultivars was not different from 'Waltham Butternut'.

In 2010 , individual fruit from 'Waltham Butternut' were heavier than 'JWS 6823' and 'Betternut 401'. Individual fruit weight of 'Metro' was not different from 'Waltham Butternut'. In 2011, individual fruit weight of all cultivars was not different from 'Waltham Butternut'.

In 2010-11, very few fruit were unmarketable and differences in unmarketable yields between cultivars were not detected.

'JWS 6823', 'Betternut 401' and 'Metro' are recommended as they performed better than or as well as 'Waltham Butternut'.

ACORN SQuash. In 2010, 'Celebration' produced a larger number of marketable fruit than all other cultivars including Table Queen. 'Autumn Delight' produced a smaller number of fruit than 'Table Queen' (Table 10). The number of fruit produced by all other cultivars was not different from 'Table Queen'. In 2011, 'Tip Top', 'REBA', 'Honey Bear', and 'Jet' produced a smaller number of marketable fruit and all other cultivars were not different from 'Table Queen'.

In 2010, marketable yields by weight from 'Tay Belle' were higher than 'Table Queen' while 'Honey Bear' yields were lower. Marketable yield by weight from all other cultivars was not different from ‘Table Queen'. In 2011, marketable yield by weight from 'Tip Top', 'REBA', 'Honey Bear', and 'Jet' was lower than 'Table Queen' which was not different from the remaining cultivars.

In 2010, individual fruit weight from 'Tay Belle', 'Autumn Delight', and 'Jet' was higher than from 'Table Queen' and lower from 'Celebration' and 'Honey Bear'. Individual fruit weight from all other cultivars was not different from 'Table Queen'. In 2011 , individual fruit weight from all cultivars was not different from 'Table Queen'.

While very few fruit were unmarketable in 2010, differences in unmarketable yields between cultivars were not detected. In 2011, 'Jet' and 'Tip Top' produced more unmarketable fruit by number and 'Jet' by weight than 'Table Queen'. All other 
cultivars produced unmarketable yields not different from 'Table Queen'.

'Celebration' is recommended as it outperformed or performed as well as 'Table Queen' in number of fruit produced and fruit weight per plant. Individual 'Celebration' fruit were lighter in 2010 and not different in 2011 than 'Table Queen'.

\section{Statewide Recommendations}

Conventional system. Results from individual locations were used to create regional recommendations. In determining whether a cultivar was suited for statewide recommendation, it must have produced comparable or superior yields to the standard over two evaluation years or at three locations in a single year.

While this crop is grown on many farms, it does not reach the economic importance of crops such as sweet corn (Zea mays) and tomato (Solanum lycopersicum). As a result, researchers in Pennsylvania, Delaware, New Jersey, West Virginia, Virginia, and Maryland share common recommendations (Orzolek et al., 2005). These cultivars can be suitable for the larger midAtlantic U.S. region as they were widely adaptable: exhibiting consistently favorable yields when grown in the varying environments encountered at each site over the two-year evaluation period and with diverse cultural methods employed at each location.

ButTERNUT SQUASH. 'JWS 6823', 'Betternut 401', and 'Metro' performed equally or superior to 'Waltham Butternut'. 'Atlas' and 'Quantum' produced large-sized fruit, which may be suited for wholesale markets. For markets with demand for a smallersized fruit, 'Bugle' is recommended.

ACORN sQUash. 'Autumn Delight', 'Harlequin', 'Table Star', 'Tip Top', 'Jet', 'Table Treat', 'Celebration', and 'Black Bellota' performed equally or superior to 'Tay Belle'. 'Harlequin' and 'Celebration' fruit was ornamental, with green, white, yellow and/or orange exocarps, in addition to being edible. Depending on market demand, they may be desirable cultivars.

BUTTERCUP/KABOCHA SQUASH. 'Red Kuri', 'Sweet Mama', and 'Sun Spot' are recommended based equal or higher yield than 'Sunshine'. The ultimate value of a cultivar is dependent on grower preference, management, site-specific environmental conditions, and the market it is destined for (Orzolek et al., 2012). Cultivars evaluated were ornamental, in addition to being edible, and largely unique from each other. In this category, ornamental value may be a larger consideration than yield-based evaluation. For example, the growercooperator participating in this study has a market for buttercup/kabocha cultivars with green exocarps; however, those with red/orange exocarps are not in demand.

\section{Organic System}

Organic and conventional systems can have unique environmental conditions (Rangarajan, 2002) because of management and production options available. As a result, performance of cultivars in these systems can differ (e.g., Aldrich et al., 2010; Reid et al., 2009). For example, organic seed and nonorganic, untreated seed were used in the organic evaluation (National Organic Standard, 2012). Cultivars meeting those criteria were much more limited than conventional seed.

Top-yielding butternut squash cultivars concurred in the organic and conventional systems, with the exception of 'Bugle' that was not assessed in the organic system because allowable seed was not available. 'Celebration' and the standard 'Table Queen' were the highest yielding acorn squash cultivars. These recommendations were different from the conventional system.

\section{Literature cited}

Aldrich, H.T., K. Salandanan, P. Kendall, M. Bunning, F. Stonaker, O. Külen, and C. Stushnoff. 2010. Cultivar choice provides options for local production of organic and conventionally produced tomatoes with higher quality and antioxidant content. J. Sci. Food Agr. 90:2548-2555.

National Organic Standard. 2012. Title 7: Agriculture. 7 Mar. 2012. <http://ecfr. gpoaccess.gov $/ \mathrm{cgi} / \mathrm{t} /$ text $/$ text-idx? $\mathrm{c}=\mathrm{ecfr} \&$ sid $=\mathrm{c} 3 \mathrm{e} 7 \mathrm{c} 1 \mathrm{~b} 5 \mathrm{a} 7 \mathrm{bdb} 911 \mathrm{db} 5 \mathrm{c} 8 \mathrm{dfb} 7 \mathrm{a} 0587$ f7 \&rgn=div8\&view=text\&node=7:3.1.1. 9.32 .3 .354 .5 \&idno $=7>$.
Orzolek, M.D., P.A. Ferretti, W.J. Lamont, T. Elkner, K. Demchak, E. Sánchez, A.A. MacNab, J.M. Halbrendt, S.J. Fleischer, L. LaBorde, K. Hoffman, and G.J. San Julian. 2005. Commercial vegetable production recommendations - Pennsylvania. Penn State Coop. Ext. Publ. AGRS-028.

Orzolek, M.D., P.A. Ferretti, W.J. Lamont, A.A. MacNab, J.M. Halbrendt, S.J. Fleischer, Z. Smilowitz, and W.K. Hock. 1999. Commercial vegetable production recommendations - Pennsylvania. Penn State Coop. Ext. Publ. AGRS-028.

Orzolek, M.D., E. Sánchez, W.J. Lamont, T. Elkner, K. Demchak, G. Lin, J.M. Halbrendt, B.K. Gugino, S.J. Fleischer, L. LaBorde, K. Hoffman, and G.J. San Julian. 2010. Commercial vegetable production recommendations - Pennsylvania. Penn State Ext. Publ. AGRS-028.

Orzolek, M.D., E. Sánchez, W.J. Lamont, T. Elkner, K. Demchak, G. Lin, J.M. Halbrendt, B.K. Gugino, S.J. Fleischer, L. LaBorde, K. Hoffman, and G.J. San Julian. 2012. Commercial vegetable production recommendations - Pennsylvania. Penn State Ext. Publ. AGRS-028.

Pennsylvania Department of Public Welfare. 2005. Winter squash. Food for Thought Nwsl. 1(7). Winter squash. 24 Apr. 2012. <http://www.panen.org/snap/ winter-squash>

Rangarajan, A. 2002. Vigor or rigor? The competing goals of variety trials. HortTechnology 12:562-566.

Reid, T.A., R.-C. Yang, D.F. Salmon, and D. Spaner. 2009. Should spring wheat breeding for organically managed systems be conducted on organically managed land? Euphytica 169:239-252.

U.S. Department of Agriculture. 2009. 2007 Census of agriculture. Volume 1, Chapter 2: State level data, Table 30. 23 Apr. 2012. <http://www.agcensus.usda. gov/Publications/2007/Full_Report/ Volume_1,_Chapter_2_US_State_Level/ st99_2_030_030.pdfs.

U.S. Department of Agriculture. 2010. 2008 Organic survey, Volume 3 Special Studies Part 2, Table 4. 20 Aug. 2012. <http://www.agcensus.usda.gov/ Publications/2007/Online_Highlights/ Organics/organics_1_04.pdf>.

U.S. Department of Agriculture. 2012. Nutritional nutrient database for standard reference, Release 24. 23 May 2012. <http://ndb.nal.usda.gov/ndb/foods/ list>. 